\title{
Shame and Absence: Feminist and Theological Reflections
}

\section{Lenart Škof ${ }^{1}$}

Published online: 2 June 2019

(C) Springer Nature B.V. 2020

'Shame and Absence: Feminist and Theological Reflections' includes contributions from seven scholars, dealing with philosophical, feminist and theological aspects of shame and absence. This collection of papers is intended as a series of interventions into some of the most precarious topics within contemporary philosophical and theological thinking related to shame and absence, including feminist aspects.

Sigridur Thorgeirsdottir (University of Iceland) begins this special issue with her paper titled 'Shame, Vulnerability and Philosophical Thinking'. In analysing deep or underlying shame, Thorgeirsdottir applies the method of embodied thinking and searches for a kind of transformative ethics, that would be able to nurture a potential future of non-violence, as a mode of our self-affection. Her task is not only to rehabilitate those allegedly shameful features of the human, but also to show how, in her words, this could transform our understanding of philosophical thinking as embodied thinking of vulnerable subjects. Morny Joy (University of Calgary) contributes to this special issue with 'Violence, Vulnerability, Precariousness, and their Contemporary Modifications'. As a scholar working within the field of religious studies, Joy brings a fascinating contemporary genealogy of women scholars from diverse disciplines, including studies in religion, who in their contributions have provided new insights into the ever-present threats to women's bodies, minds, and lives. She notes especially the contributions from Sally Engle Merry, Grace Marion Jantzen, Ann V. Murphy and Pamela Sue Anderson. Morny Joy analyses their interventions at the intersections of violence, vulnerability and precariousness to show how their important insights have helped to transform the philosophy of religion as a scholarly discipline into a new undertaking that can inspire and not confine women. Kelly Oliver (Vanderbilt University) continues with 'Shame, Depression, and Social Melancholy' in which both themes of shame and absence are correlated. Within her contribution, social melancholy is delineated as a form of melancholy that results from oppression, domination and the colonization of psychic space. Oliver deals with the critique of a

Lenart Škof

lenart.skof@guest.arnes.si

1 Science and Research Centre Koper, Institute for Philosophical Studies, Garibaldijeva 1, 6000 Koper, Slovenia 
stereotypical femininity and continues with the distinction between shame and guilt that in her opinion was missing from traditional psychoanalytic accounts of melancholy and depression. Oliver shows that if there are no representations of girls and women in which negative effects caused by oppression could be discharged, then these women become melancholic subjects. Zeynep Direk (Koç University), a philosopher from Turkey, concludes the part on shame and vulnerability with her article 'Politics of Shame in Turkey: Public Shaming and Mourning' in which she takes into account the phenomenological and psychological theories of shame to analyze for the structure of the contemporary phenomena of public shaming in the social media in Turkey. Direk first delineates shame and guilt and offers a reflection on their political meanings ignoring the particular vulnerability of subjects being ashamed. Based on her fine analyses of shame and its consequences in the thought of Sartre, Lacan, and Levinas, Direk continues with the feminist and political aspects of shaming, aggression, and silencing within the public space and media (especially of women, but not limited to them) and concludes with concrete case studies dealing with political injustices and related strategies of shame.

In his 'Silence and Absence: Feminist Philosophical Implications of Mormonism's Heavenly Mother', Taylor Petrey (Kalamazoo College) opens our next section and focuses on the theological aspects of an absence. Petrey concentrates on Mormonism and its teaching of the Heavenly Mother. According to Petrey, feminist philosophers of religion have often argued for the importance of a divine feminine as a challenge to patriarchal religion but still the Heavenly Mother tradition has not created an egalitarian religion in Mormonism. In this paper, Mormonism's complicated yet strong potential for such move is presented on the one side, and the absence and silence of speech by or from women in various Christian traditions on the other side. Petrey shows convincingly that silence can be both oppressive and strategic and asks himself what kind of power may be revealed if we were to focus not on silence about Heavenly Mother, but rather silence from Heavenly Mother; thinking through an analysis of Her silence and absence? 'The Missing Hymn of Metis: An Origin of Loss' of Shé M. Hawke (University of Sydney) excavates a hidden genealogy of maternal divinity through the undertold story of Athena and her mother Metis. Psychoanalysis, philosophy and popular myth predominantly deem Athena un-mothered and born from the head of Zeus. Hawke disrupts this discourse, by naming the lost mother Metis, an Olympic deity in her own right, and asserts that Athena was raised in ignorance of both the existence of her mother Metis, and Zeus's murder of her mother, thereby dis-figuring effective grievability of the first love object. This overlooked mother/daughter drama narrates an origin of divine maternal loss, and an origin of terror and gender violence. Hawke carefully applies the work of Anderson, Joy, and Irigaray to re-figure mother/ daughter relationships, while contesting Freud's disabling hegemonic analysis that all women are dispositionally hysterical or melancholic.

Finally, Lenart Škof (Science and Research Centre Koper) concludes this special issue with his paper titled 'The Third Age: Reflections On Our Hidden Material Core' in which the model of the three eras is presented and analysed with the method of philosophical theology. In the forefront of these analyses are Joachim of Fiore and Amalric of Bène. Škof argues that even in these secular times, the salvation history still remains unfulfilled and that our world is in need of a new, post-Christian materiallyspiritual narrative which already was provided by Amalricians and their teachings but 
still lies hidden and, as it were, is absent from the prevailing theological narratives. In the concluding part of this paper, the age of the spirit is therefore approached and defined as a future messianic era in which humanity will be spiritually transformed and divinized. As a guest editor of this collection of papers, I want to express my thanks to the editors of Sophia for accepting it for this special issue. My sincere thanks also go to the Sophia editorial team - especially Purushottama Bilimoria, and also Sherah Bloor, Jennyca Parcon, and Xavier Castanos - for their continuing support and assistance in the process of its publication. Finally, I want to express my deepest gratitude to all contributors to this special issue for their dedicated work. 